Journal of Digitovation and Information System

$\underline{\text { http://jdiis.de/index.php/jdiis }}$

\title{
Factors Influencing the Usage of Instagram for Business and its Effect on Financial Performance and Non-Financial Performance
}

\author{
Altaf Akbar* \\ Department of Management, University of Aveiro, Portugal,
}

\begin{abstract}
The objective of this article is to study the factors which affect the Small and Medium Enterprises (SMEs) instagram use for business and its subsequent impact on financial and non-financial performance. The primary purpose of this study is to examine the effect of competency, cost-effectiveness, innovative behavior, and interactivity on instagram use for business, and consequences on firms' performance. Statistical analysis was performed on the data acquired through a survey questionnaire from 352 Malaysian SME employees. The findings revealed that competency, cost-effectiveness, innovative behavior, and interactivity have a positive influence on instagram use for business. The results also indicated that instagram use for business has a strong positive effect on the financial performance and non-financial performance of SMEs. All the hypotheses were accepted and tested by a partial least square (PLS) approach.

Keywords

Social media, Competency; Cost-effectiveness; Innovative behavior; Interactivity; Instagram; SME
\end{abstract}

Article Information

\section{Introduction}

Advancement in information technology resulted in a variety of revolutionary businesses (Ostrom, Parasuraman, Bowen, Patrício, \& Voss, 2015). Evidently, the prevalence of the internet has also given consumers a plethora of uses on the web, bringing a significant change in the conduct of businesses. In recent times, social media and social interacting sites have become the leading forums for the development and management of transactional and interpersonal activities within companies (Kaplan \& Haenlein, 2010) as well as brand management and communication (Ashley \& Tuten, 2015). Social media are used by people to digitally advertise their goods and communicate with consumers effectively. Instagram has emerged as the most popular social media platform, particularly for businesses and entrepreneurs. In recent years, instagram has become a new marketing communication tool at a rapid and dynamic pace. Moreover, instagram features such as photos, video, sales, publicity, promotion, messaging, and comments are designed to facilitate Small and Medium Enterprises (SMEs) employees to reach customers without time and space (Agung \& Darma, 2019). Some studies suggest social media usage is particularly suitable for SMEs because of its minimal cost, low barriers to participation, mobility, and low level of IT required skills (Breslauer \& Smith, 2009; Durkin, McGowan, \& Murray, 2014; Odoom, Anning-Dorson, \& Acheampong, 2017; Toole, 2011). SME can customize their publicity method as per customers' demand alongside publicity it helps the SME to receive the customers' opinion about the products (Paniagua \& Sapena, 2014; Parveen, Jaafar, \& Ainin, 2015). Considering the customers' opinions novel and active networking practices benefit the escalation of entrepreneurial business performance and success (Charoensukmongkol \& Sasatanun, 2017) that is intrinsically tied to the financial performance of a business (Kim \& Kim, 2018), (Gwadabe \& Amirah, 2017). Spita, Peitzika, and Chatzi (2020) studied social media experience, satisfaction from the use of social media and suggested investigating interactivity, costeffectiveness, innovative behavior, and competency in the social media context. Previous studies have investigated that compatibility, trust (Sajilan, Tehseen, Yafi, \& Ting, 2019) antecedents of consumer intention (Casaló, Flavián, \& IbáñezSánchez, 2020; Orús et al., 2016) firm strategy, and social media adoption that positively influence social media usage. Scholars have examined, social media interactivity, customers' likes on posts (Agostino \& Sidorova, 2016) technological constructs, and social media usage (Odoom et al., 2017) social media as a marketing tool (Ashley \& Tuten, 2015) customer loyalty, employee efficiency, and technological advancement (Abdallah \& Alnamri, 2015) and their positive influence on the financial and non-financial performance of SMEs. Previous studies discuss factors like compatibility, trust, interactivity, cost-effectiveness. 
However, the studies lack in exploring the influence of innovative behavior and competency on instagram use for business in terms of financial performance and non-financial performance in SMEs. In recent times, avenues such as social media are being used by small businesses in both developing and developed economies for a range of functions, including but not limited to marketing and customer relationship management. Therefore keeping in sight the above-mentioned gaps the current study investigates four antecedents competency, cost-effectiveness, innovative behavior, interactivity that influence instagram use for business, as well as to demonstrate the effect of instagram usage on financial performance and non-financial performance.

The study is based on the Diffusion of Innovation (DOI) theory that is increasingly used to investigate intention to adopt and actual adoption of technology. Innovation means improvements in the use of media or media websites (Parveen et al., 2015). The innovation may take on the shape of a product, service, concept, knowledge, or experience that people experience as unique (M. Rogers, 2004). Generically speaking, the innovation could be viewed as something new for the adopting institution's application but not entirely new in itself on the date of production of items ( $\mathrm{Zhu}$, Hao Yang, Xu, \& MacLeod, 2020). Furthermore, instagram and Facebook are social network websites that might be seen as innovation elements (Archibald \& Clark, 2014). By giving an effective competitive edge through its application, the innovation of instagram can benefit your business (Abbas \& Ul Hassan, 2017). The innovation attribute competency was investigated in this study using the DOI theory, interactivity, cost-effectiveness, and innovative behavior on social media were also included.

The primary objective of this research is to evaluate the effects of competence, cost efficiency, innovative behavior, and interaction on instagram use as well as to demonstrate the financial performance, non-financial performance. This study has the key research questions,

1. What is the effect of competency, cost-effectiveness, innovative behavior, interactivity on instagram usage?

2. How does the usage of instagram affect financial performance, non-financial performance?

\section{Literature review and research framework \\ 2.1. Theoretical foundation}

This study follows the theoretical foundation of diffusion of innovation (DOI) theory that explains the mechanism by which an innovation can be introduced and applied for a variety of purposes within organizations or between individuals over time (Bass, 1969; Maddux \& Rogers, 1983). The DOI theory focuses on the purpose and stage of technological adoption (Doyle, Su, \& Kunkel, 2020; Honey \& Raphael, 2017; Sajilan \& Tehseen, 2019). DOI theory has shown how SMEs utilize Facebook to enhance their retail business (Sajilan et al., 2019). Employing the DOI theory, this study assessed the factors such as competency, cost efficiency, innovative behavior, and interactive behavior as an antecedent for instagram usage in Malaysian retail SMEs (Sajilan et al., 2019).

\subsection{Adoption of social media usage}

Internet-enabled communication media has supported many organizations to conduct their businesses from anywhere across the globe (Chen, 2016). Knoll (2016) for instance reports that social media has become part of human lives, especially among internet users. According to Stokes (2013), more than a third out of four of the world's internet user population will hook onto social network sites by the close of 2016. Other reports reveal that more than 1 billion internet users have been watching videos on YouTube monthly (Orús et al., 2016). At the firm level, the use of social media among Fortune 500 companies surged massively in 2012 (Okazaki \& Taylor, 2013) with as many as 66\% having corporate Facebook pages and $73 \%$ having official corporate Twitter account aside from the numerous corporate blogs. Evidence suggests that the figures are on the ascendancy each year (McCann \& Barlow, 2015). This unceasing increase according to Okazaki and Taylor (2013) denotes a long-term trend or norm towards social media use among corporations (and individual brands). Consequently, social media has become an auspicious platform for both firms and consumers to transact and relate to each other in a conducive and mutually valuable manner (Kumar, Bezawada, Rishika, Janakiraman, \& Kannan, 2016).

Research has shown that the adoption of instagram usage yields substantial benefits for SMEs. Marketers have the opportunity not only to transmit information about a product or service but also to conduct marketing research and receive useful feedback from customers while monitoring travel reviews and comments for a better understanding of their needs, preferences, attitudes, and buying behaviors (Leung, Law, Van Hoof, \& Buhalis, 2013). Consumers' feedback provides the opportunity to tourism organizations to customize their marketing and sales efforts and provide personalized and specialized services that satisfy individual specific needs. Alongside, other benefits identified in the relevant literature include the enhancement of corporate image (Monica \& Balaş, 2014) the building and enhancement of global brand awareness, the strengthening of brand equity, the development of a unique brand identity, the augmentation of e-WOM positive communication (Ashley \& Tuten, 2015; Trusov, Bucklin, \& Pauwels, 2009), the reduction of marketing costs (Molla \& Heeks, 2007), the increase in purchase intentions (Colliander \& Dahlén, 2011), the upgrade of search engine rankings, and the increased traffic in SMEs official website (Lebherz, 2011). 


\subsection{Impact of competency on instagram usage}

Based on the DOI theory, competency refers to an individual's capacity to use social media appropriately as a means to send messages, engage with others, and encourage conversation and participation in a community (Alber et al., 2015). Competency is an essential factor for the efficient use of an accounting information system and its overall success (Daoud \& Triki, 2013). Competency-based approach is also a crucial criterion for personnel selection in the field of information technology (Rahman et al., 2021). Many researchers have investigated the influence of competency on social adoption and found both positive and negative results. For instance, Napitupulu and Dalimunthe (2015) highlighted the significant effect of the users' competency of information systems on the quality of the management accounting information systems. Kettunen (2017) discussed the significant effect of competency in career services. Besides these studies, there is a need in the future to investigate the linkage between entrepreneurial competency, social competency, and social media usage in the entrepreneurial domain (Soong, Jalil, Ayyasamy, \& Akbar, 2019). In the current study context, it is proposed to study the influence of competency on instagram usage. Hence, to test the relationship, the following hypothesis is proposed

H1: Competency positively and significantly influences instagram usage.

\subsection{Impact of cost-effective on instagram use for business}

Apart from the innovation attributes suggested by Lundblad (2003), the cost is conceptualized in this study as the perceived cost-effectiveness of social media. Studies have found cost-effectiveness to be an important variable in the adoption of new technologies (Ramdani, Chevers, \& Williams, 2013). This cost-effective nature of social media attracts not only large multinational organizations but also SMEs and even nonprofit and governmental agencies (Kaplan \& Haenlein, 2010). Therefore, the cost-effectiveness of social media can be considered as one of the important factors that are associated with social media usage in SMEs. However, scholars have recommended social media outlets as cost-effective and efficient platforms available to marketers (Ainin, Parveen, Moghavvemi, Jaafar, \& Shuib, 2015) granted that such outlets have become relatively free in terms of accessibility for both firms and consumers (Baumöl, Hollebeek, \& Jung, 2016). In addition, generating target groups, as well as disseminating systematic advertising and promotions to these groups is possible at relatively lower costs (Dong-Hun, 2010) via social media. Since most social media sites are free for signing up, the cost is often associated with the time spent on posting/blogging status messages, and responding to customer comments (Zappe, 2010). Aside from being relatively cheaper platforms, social media enable effective expansion in collaborative content sharing to large numbers of people across geographic distances (Korda \& Itani, 2013). The cost of reaching customers beyond such boundaries could be higher via traditional media. With over 1 billion users on both Facebook and Twitter for instance, consumers are currently moving away from traditional media as means of obtaining information on products and services. As such, firms now have the benefit of deploying innovative strategic brand communications that effectively engage and reach their customers in countless ways, via platforms that do not require highly priced media spends and creativity (Hanna, Rohm, \& Crittenden, 2011).

In the light of the above discussion, the following hypothesis is proposed.

H2: Cost-effectiveness positively and significantly influences instagram usage.

\subsection{Impact of innovative behavior on instagram usage}

Innovation is a key strategy for the efficiency and productivity of the enterprise. Companies view innovation as a means of gaining a competitive advantage and achieving organizational success (Jafri, 2010). Continued environmental trends are leading industries to adopt new strategic approaches and strategies, including increasing competition, globalization of markets and companies. Innovative behavior refers to an employee's intentional introduction or application of new ideas, products, processes, and procedures to his or her work role, work unit, or organization such as searching out new technologies, suggesting new ways to achieve objectives, applying unique work methods, and investigating and securing resources to implement new ideas (Yuan \& Woodman, 2010). Furthermore, the innovative behavior of employees is a valuable attribute for a company to compete in a competitive market world (Yuan \& Woodman, 2010). Examples of these behaviors include exploring the new emerging technology, new means of achieving goals, new methods of work (Huang, Yuan, \& Li, 2019). Previous studies have investigated the positive influence of innovative behavior on work agility (Bala, Massey, \& Seol, 2019) social media usage (Mansour \& Al-Najjar, 2018), and transformational leadership (Shunlong \& Weiming, 2012). The following hypothesis is developed based on the above explanation.

H3: Innovative behavior significantly influences instagram usage. 


\subsection{Impact of interactivity on instagram use for business}

Based on the DOI theory, as suggested by E. M. Rogers (1995) interactivity is the degree to which two or more communication parties can act on each other, on the communication medium, and on the messages and the degree to which such effects are synchronized (Liu \& Shrum, 2002). Thus, interactivity is characterized by two-way communication between firms and/or among customers (Goldfarb \& Tucker, 2011). The social context of social media emphasizes the interaction on an individual/interpersonal level or a collective intergroup level (Rutter, Roper, \& Lettice, 2016) which often requires some degree of responsiveness, particularly from firms. In such circumstances, the immediacy of the responsiveness and the degree to which the communication bears a resemblance to human dialogues becomes imperative (Bao, Li, Shen, \& Hou, 2016; H. H. Lee, Fiore, \& Kim, 2006). Thus, the virtual presence requires the need to synchronously communicate and engage with consumers in real-time, as well as obtain effective and impactful interactions (Elaluf-Calderwood, Kietzmann, \& Saccol, 2005).

Although characterized as interactive, differences exist among social media concerning the nature of interactions they support (Quan-Haase \& Young, 2010), resulting in a variety of gratifications within several organizations. Sundar, Kalyanaraman, and Brown (2003), conceptualize two major classifications of interactivity; the first one is functional interactivity which comprises the features found on a social site that allows users to interact within several modes, and second is contingency interactivity which occurs when users' roles are interchangeable and the interactants are responding to one another. Facebook and Twitter for instance enable contingency interactivity among its publics by offering a relationship-building kind of communication that is often lacking from websites (Saffer, Sommerfeldt, \& Taylor, 2013). Yamamoto and Miyashita (2008) suggest that having a social media presence alone is not enough for organizations. It is argued that this should be complemented with customer interactions. Lovejoy and Saxton (2012) in this regard point out that contingent interactive features like replies and mentions enable organizations to communicate with their customers. Interactivity ultimately bridges the gap created by the disparity in time and geographical location (Karampela, Lacka, \& McLean, 2020) becoming a key consideration for adopting social media. Considering the above discussion following hypothesis is proposed.

H4: Interactivity positively and significantly influences instagram usage.

\subsection{Impact of instagram use for business on organizational performance}

Previous studies have investigated the relationship between system use and its impact on performance and have found significant results. For instance, it was found that higher internet usage increased the impact it would have on organizations in terms of increased revenue, enhanced relationships, and reductions in cost and time (Parveen, Jaafar, \& Ainin, 2016). Shuai and $\mathrm{Wu}(2011)$ in their attempt to study e-marketing, found that an internet marketing tool is positively associated with the firm's performance. In the context of social media, literature claims that social media can have a dramatic impact on organizations in digital advertising and promotion, handling customer service issues, mining innovative ideas, and building customer relations (Dodokh \& Al-Maaitah, 2019). Therefore, when organizations use social media effectively for various tasks, like marketing, customer relations, and information searching, it is likely to have a positive impact on the organizational performance, especially in terms of cost reductions, improvements in customer relations, and enhanced accessibility of information.

Social media may influence financial performance by enabling users in social media to assess and estimate demand (Paniagua \& Sapena, 2014). Ashley and Tuten (2015) suggested that companies use social media as a marketing strategy to increase revenues and incomes. Furthermore, the distinction or cost-efficient approach has an indirect but significant effect on the efficiency of the company (Teeratansirikool, Siengthai, Badir, \& Charoenngam, 2013). Companies that increase their participation in social media have increased sales (Al-kalouti et al., 2020). Similarly, social media currently plays a vital role for small companies, particularly because it generates greater awareness of brands and better connections to achieve sales and retail sales for small enterprises (Jones et al., 2015).

In the context of non-financial performance, increased interactivity through the use of social media can influence consumer sentiment with financial and non-financial consequences (Agostino \& Sidorova, 2016). Abdallah and Alnamri (2015) report that companies can boost their non-financial performance through customer loyalty, employee enthusiasm, and technical innovation. In social media companies may also adapt branding or marketing to the needs of customers and wish to have views and reviews on their latest goods (Paniagua \& Sapena, 2014; Parveen et al., 2015). This can be empirically tested by proposing the following hypotheses.

H5: Instagram usage significantly influences financial performance.

H6: Instagram usage significantly influences non-financial performance. 


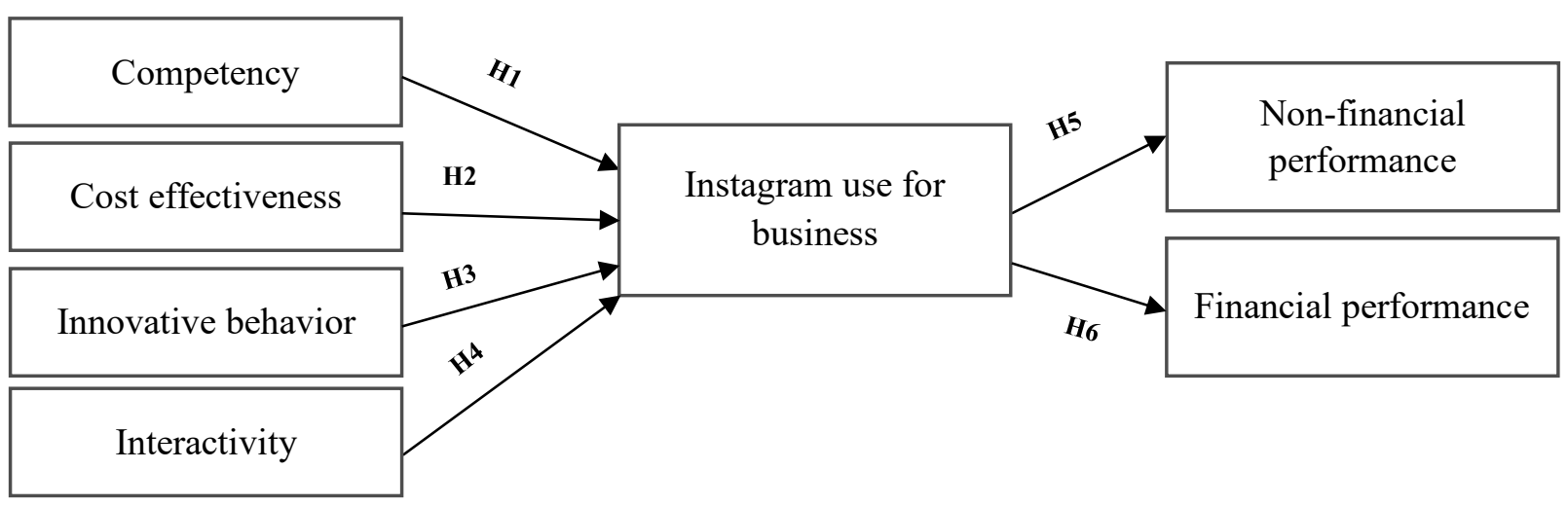

Figure 1: Proposed Research Framework

\section{Methodology}

\subsection{Procedure and participants}

The research setting for this research is SMEs in Malaysia that utilize instagram for their companies. The sales turnover or the number of workers might characterize SMEs. Micro enterprises have revenue of less than RM 300,000 or workers of fewer than 5 full-time. Small businesses are generating revenues between RM300000 and RM3 million (or between five and 30 full-time workers), with medium-sized companies with revenues between RM3 million and at least RM20 million (World Emerging Markets, 2013).

To collect data for the study, the researcher initially contacted numerous SMEs in Malaysia by email. The administrative department was contacted to obtain permission to conduct the survey while explaining the study objectives and purpose. The researcher also provided the confidentiality agreement to utilize study data for this study only and to share the study results with the managers allowing permission for conducting the survey, while maintaining the anonymity of their employees and ensuring privacy. The researcher also provided a sample questionnaire for getting the final approval for data collection. The HR managers then supplied a list of employee emails IDs while keeping the names of the employees confidential to reduce bias and any ethical issues from arising.

After obtaining the employee email id's list the researcher randomly circulated 1000 questionnaires to various employees of the SME, utilizing random sampling technique by selecting every 2 nd employee N-2 on the list provided by the human resource managers that contained employees' email Ids. The decision for using email and online surveys was due to Covid-19 restrictions, the company's policy to maintain the confidentiality of employees, and the low budget and time at hand for the researcher. Also, the online survey provided quick responses with less bias and intervention of the researcher, compared to traditional face-to-face surveys, and as most of the employees were unavailable due to work from home restrictions by the government due to the current pandemic.

The data was collected using a questionnaire that was divided into two sections. The first section contained information regarding various demographics, including age and gender of employees, SMEs employees' experience. The second section contained items regarding study latent variables competency, cost-effectiveness, innovative behavior, and interactivity. The questionnaire was circulated among 1000 employees selected randomly, of the SME in January 2020. The researcher sent soft reminders after three weeks and hence received 570 filled questionnaires by the first week of February 2020. The employees were sent two reminders after a week, and by the end of the first week of March 2020, the researcher received complete responses of 520 circulated questionnaires at the start of March 2020. In total, 470 complete responses were received generating a response rate of $47 \%$ for circulated 1000 initial questionnaires. Out of which 118 were discarded due to incomplete responses, missing values, and Outliers. This left the researcher with 352 usable questionnaires.

\subsection{Instrumentation}

This research includes questions on the structures of interest. The five-point Likert scale of " $1=$ Strongly Disagree and $5=$ Strongly Agree" was used to measure all of the assertions. The seven variables of interest in this study competency, costeffectiveness, innovative behavior, interactivity, instagram use for business non-financial performance, and financial performance were all measured using items taken from previously validated scales. Each variable was measured by using its three items. Competency was measured using items from Stratman and Roth (2002) and E. M. Rogers (1995) 3 items measure innovative behavior (Messmann \& Mulder, 2012; Scott \& Bruce, 1994), items to measure interactivity were adapted from Y. Lee and Kozar (2012), to measure instagram use for business items were adapted from Elliot and Boshoff (2005), non-financial performance was measure by using the scale of 3 items from Teo and Choo (2001), and financial 
performance was measured using 3 items from (Ainin et al., 2015).

\subsection{Data analysis techniques}

The Partial Least Square (PLS) applications were used for data analysis of the demographic characteristics, hypothesis testing and to provide the primary data understandably and satisfactorily.

\subsection{Results}

\subsubsection{Demographics analysis}

The online survey method was used in this study to collect data from Malaysian SMEs. The survey was distributed among 1000 employees, out of which 470 respondents had completed the full survey. Further in the process of data cleaning, 352 responses were found useful after removing erroneous and missing data, giving a $47 \%$ response rate. The sample included 89 (25\%) females and $263(75 \%)$ males. The age of study respondents ranged between 25 years to 55 years. About the SMEs working experience, $40 \%$ of employees were having $4-6$ years, $29 \%$ were between $2-4$ years, and the less percentage was noticed for $0-2$ years (i.e. $14 \%$ ) and more than 6 years (17\%). Table 1 shows the descriptive statistics of the demographic variables.

\begin{tabular}{lccc}
\multicolumn{3}{l}{ Table 1: Descriptive statistics } \\
\hline Demographics & Categories & Frequency & Percentage \\
\hline Age Group & $25-30$ & 135 & $38 \%$ \\
& $31-40$ & 159 & $45 \%$ \\
& $41-55$ & 58 & $16 \%$ \\
Gender & Male & 89 & $25 \%$ \\
& Female & 263 & $75 \%$ \\
SME & $0-2$ year & 49 & $13 \%$ \\
Experience & $2-4$ year & 101 & $28 \%$ \\
& $4-6$ years & 142 & $40 \%$ \\
& $>6$ years & 60 & $17 \%$ \\
\hline
\end{tabular}

\subsubsection{Measurement model analysis}

The measurement model evaluation assesses the items and their corresponding constructs (J. F. Hair, Risher, Sarstedt, \& Ringle, 2019). This study used the technique partial least square (PLS) to analyze data using SmartPLS 3.3 to validate measurements and test the hypothesis. Internal consistency (composite reliability), reliability test (outer loadings), convergent validity, average variance extracted (AVE), and discriminant validity are all factors that are considered when evaluating the measurement model. As suggested by J. Hair, Hollingsworth, Randolph, and Chong (2017) Cronbach's alpha suggested benchmark is .70 , while the value for composite reliability .70 to .90 is acceptable. The findings revealed Cronbach's alpha values ranged from .7 to .9 and composite reliability from .8 to .9 fall within the acceptable benchmarks. The AVE values .50 to .68 were all above .5 confirming the convergent validity. Furthermore, all VIF values, ranging from 1.19 to 3.58 , were below 10, confirming that multicollinearity was not present (J. Hair et al., 2017). The second criterion for evaluating reflective models is to examine the validity of discrimination. The results of the Fornell and Larcker (1981) criterion indicated that the AVE square root is greater than the correlation value of other inter-constructs Table 2. As a result, discriminant validity has been attained.

Table 2: Discriminant Validity

\begin{tabular}{llllllll}
\hline & CP & CE & IB & IT & FP & NFP & IUFB \\
\hline Competency & .74 & & & & & & \\
Cost Effectiveness & $.25^{* *}$ & .82 & & & & & \\
Innovative Behavior & $.32^{* *}$ & $.19^{* *}$ & .78 & & & & \\
Interactivity & $.17^{* *}$ & $.20^{* *}$ & $.41^{* *}$ & .70 & & & \\
Financial Performance & $.13^{*}$ & $.44^{* *}$ & $.26^{* *}$ & $.23^{* *}$ & .87 & & \\
Non-Financial Performance & $.55^{* *}$ & $.31^{* *}$ & $.30^{* *}$ & $.13^{*}$ & $.29 * *$ & .79 & \\
Instagram Use for Business & $.10^{* *}$ & $.44^{* *}$ & $.23^{* *}$ & $.22^{* *}$ & $.21^{* *}$ & $.10^{* *}$ & .80 \\
\hline
\end{tabular}


The standardized loadings of all items were above the suggested benchmark of .5 (J. Hair et al., 2017). We examined the study question relating to the loading of the 22-item factor for measuring construct validity by way of Exploratory Factor Analysis (EFA). The applicability of an EFA using the Sphericity test of Bartlett and the Kaiser Meyer Olkin (KMO) sampling measurement in each data set to establish the multivariate normality and sampling adequacy was examined. For the factor analysis, a statistically significant value is required for Bartlet's Sphericity test and samples of a KMO suitability value of .5 or above (J. Hair et al., 2017). After examining the final data set, Bartlett's test of Sphericity yielded a statistically significant value and the KMO measure of sampling adequacy was excellent (.889). As seen in Table 3, all loadings are higher than the .70 cutoff value (J. Hair et al., 2017).

Table 3: Reliability and Validity

\begin{tabular}{|c|c|c|c|c|c|}
\hline Variables & Items & $\begin{array}{c}\text { Cronbach's } \\
\text { Alpha }\end{array}$ & $\begin{array}{c}\text { Factor } \\
\text { Loading }\end{array}$ & $\begin{array}{l}\text { Composite } \\
\text { Reliability }\end{array}$ & $\begin{array}{c}\text { Average } \\
\text { Variance } \\
\text { Extracted }\end{array}$ \\
\hline \multirow[t]{3}{*}{ Competency } & Com1 & .74 & .73 & .78 & .55 \\
\hline & Com2 & & .69 & & \\
\hline & Com3 & & .79 & & \\
\hline \multirow[t]{3}{*}{ Cost-effectiveness } & CE1 & .87 & .85 & .86 & .68 \\
\hline & CE2 & & .87 & & \\
\hline & CE3 & & .73 & & \\
\hline \multirow[t]{3}{*}{ Innovative behavior } & IB1 & .78 & .84 & .82 & .61 \\
\hline & IB2 & & .73 & & \\
\hline & IB3 & & .68 & & \\
\hline \multirow[t]{3}{*}{ Interactivity } & Int 1 & .81 & .87 & .85 & .49 \\
\hline & Int2 & & .73 & & \\
\hline & Int3 & & .83 & & \\
\hline \multirow[t]{3}{*}{ Financial performance } & FP1 & .74 & .65 & .84 & .76 \\
\hline & FP2 & & .83 & & \\
\hline & FP3 & & .69 & & \\
\hline \multirow[t]{3}{*}{ Non-financial performance } & NFP1 & .77 & .83 & .83 & .63 \\
\hline & NFP2 & & .72 & & \\
\hline & NFP3 & & .89 & & \\
\hline \multirow[t]{4}{*}{ Instagram use for business } & Use1 & .89 & .75 & .84 & .64 \\
\hline & Use2 & & .76 & & \\
\hline & Use3 & & .75 & & \\
\hline & Use4 & & .89 & & \\
\hline
\end{tabular}

\subsubsection{Assessment of structural model}

The significance and relevance of the constructs were assessed by PLS-SEM through bootstrapping by using 1000 samples. The results of all hypotheses are shown below in Table 4 . Table 4 represents the direct impact of competency on instagram use for business. Following the recommendations of J. Hair et al. (2017) bootstrapped t values of 1.96 or higher were taken as indications of statistical significance at $\alpha .05$. The results of $\mathrm{H} 1$ are supported as t-value is more than 1.960 $(\beta=.672, t=4.873, P=.000)$. This means the positive impact of competency on instagram use for business is significant. The results of $\mathrm{H} 2$ are supported due to $\mathrm{t}$ value $(\beta=.355, \mathrm{t}=1.982, \mathrm{p}=.050)$. This means the positive impact of costeffectiveness on instagram use for business is significant. The result of $\mathrm{H} 3$ is supported due to the significant value of $\mathrm{t}(\beta$ $=.734, \mathrm{t}=2.015, \mathrm{p}=.050$ ). This means that the positive impact of innovative behavior on instagram use for business is significant. The results of $\mathrm{H} 4$ are supported $(\beta=.424, \mathrm{t}=7.322, \mathrm{p}=.000)$ which shows the positive and significant impact of interactivity on instagram use for business. The result of $\mathrm{H} 5$ is also supported $(\beta=.532, \mathrm{t}=6.213, \mathrm{p}=.000)$ which reveals that the positive influence of instagram use for business on non-financial performance is significant. The finding of H6 is also supported $(\beta=.687, t=2.568, p=.010)$ showing the positive impact of instagram use for business on financial performance is significant. The study results showed that all hypotheses $(\mathrm{H} 1, \mathrm{H} 2, \mathrm{H} 3, \mathrm{H} 4, \mathrm{H} 5$, and H6) are supported in the study, Table 4 Summarizes the results of hypotheses testing. 


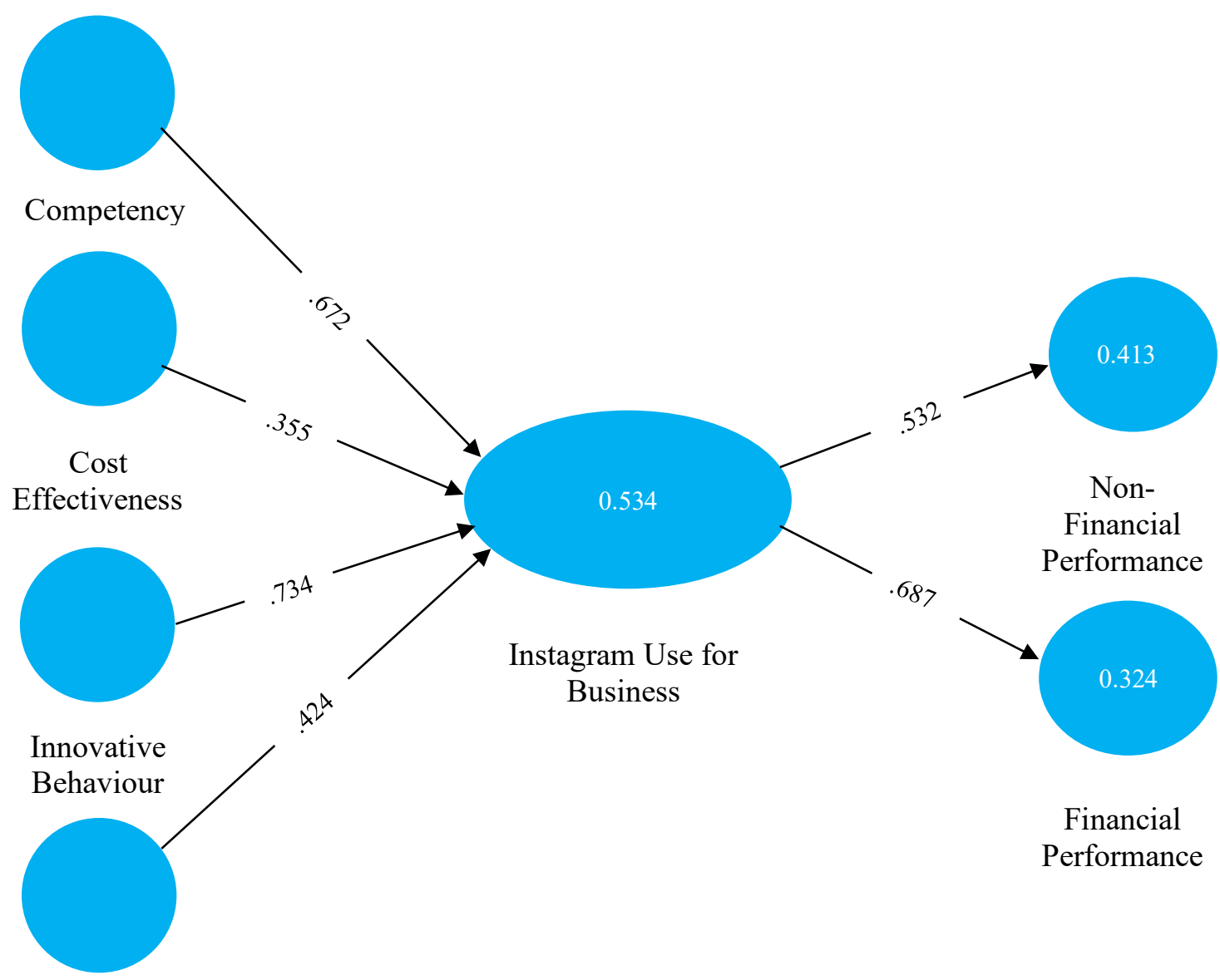

Interactivity

Table 4: Summary of hypotheses testing

\begin{tabular}{|c|c|c|c|c|}
\hline Hypothesis & $\begin{array}{c}\text { Standardized } \\
\text { Coefficient }\end{array}$ & T-Value & P Values & Results \\
\hline $\begin{array}{l}\text { Competency } \rightarrow \text { Instagram Use for } \\
\text { Business }\end{array}$ & .672 & 4.873 & .000 & Supported \\
\hline $\begin{array}{l}\text { Cost Effectiveness -> Instagram Use for } \\
\text { Business }\end{array}$ & .355 & 1.982 & .050 & Supported \\
\hline $\begin{array}{l}\text { Innovative Behaviour -> Instagram Use } \\
\text { for Business }\end{array}$ & .734 & 2.015 & .050 & Supported \\
\hline $\begin{array}{l}\text { Interactivity } \rightarrow \text { Instagram Use for } \\
\text { Business }\end{array}$ & .424 & 7.322 & .000 & Supported \\
\hline $\begin{array}{l}\text { Instagram Use for Business->Non- } \\
\text { Financial Performance }\end{array}$ & .532 & 6.213 & .000 & Supported \\
\hline $\begin{array}{l}\text { Instagram Use for Business -> Financial } \\
\text { Performance }\end{array}$ & .687 & 2.568 & .010 & Supported \\
\hline
\end{tabular}

\section{Discussion and conclusion}

This study provides a clear understanding of the antecedents and benefits of instagram usage and provides a holistic view of instagram usage in organizations from different industries and of different sizes, creating the opportunity to transfer these results to other contexts. The findings of the antecedents of instagram usage revealed that competency is positively associated with Instagram use for business $(\mathrm{P}<.00)$. The result on competency was consistent with the previous studies, which argued that competency is an important factor in the adoption of any new technology (Rahayu \& Day, 2015). 
Similarly, the interactivity of instagram is also an important factor that determines the use of social media in organizations $(\mathrm{P}<.00)$. The result was consistent with the previous studies, which suggested that interactivity of the technology has a strong effect on instagram usage (Y. Lee \& Kozar, 2012). The interactive nature of instagram enables two-way communication with the public, which motivates organizations to use it. Interactive innovations provide two-way communication and speed up the adoption process of instagram usage because they attract users quickly (S. Lee \& Cho, 2011). Another antecedent of instagram usage is innovative behavior $(\mathrm{P}<.05)$ has a positive effect on the usage of social media. The findings of current studies were consistent with previous studies, which argued that innovative behavior is an important determinant of social media usage (Park, Song, Yoon, \& Kim, 2014). Cost-effectiveness was also found to be significant with social media usage (Tan, Chong, Lin, \& Eze, 2009), where social media is considered cost-effective, but there may be costs in terms of employing dedicated staff to continuously monitor, update, and respond to customer queries. Moreover, running a campaign on social media also incurs costs. This study revealed that cost-effectiveness is a significant factor in organizational usage of social media.

The result of this study also shows that instagram use for business has a very strong positive impact on an organization's performance $(\mathrm{P}<.00)$, in terms of financial performance and non-financial performance. Social media provides interactive communication with current and potential future customers, and this benefits the organization in terms of enhanced customer relations. Social media also helps to retrieve more information about the organization's competitors, their activities, their tactics, and their brand sentiments, which helps them to enhance their products and services to achieve a greater impact on organizational performance (Parveen et al., 2015). The result is also consistent with previous findings that found positive relationships between social media usage and firm performance (Ahmad, Bakar, \& Ahmad, 2019).

\subsection{Practical implications and limitations}

The above results provide new findings and directions for SMEs marketers - who want to embrace the new social media marketing trends and develop a dynamic online presence. The empirical evidence from this study offers a deeper understanding of the factors that influence social media use and enhances confidence in marketing managers, to further stimulate the use of social media tools as they contribute significantly to the increase of financial performance and nonfinancial performance. Merely introducing ICT elements may not be enough to boost SMEs' financial and non-financial performance (Sirirak et al., 2011). In particular, the degree of social media adoption is what matters the most to enhance performance levels. Knowing the factors that accelerate the use of social media tools for marketing and communication purposes can serve strategically in the following directions: to an increase of financial performance and non-financial performance, profitability, and customer satisfaction. Thereafter, the ignorance of the factors that ensure sufficient social media use, and consequently the failure of SMEs to engage in social media platforms. The findings support that social media deployment can both affect the financial and non-financial performance of SMEs, as it is directly linked to SMEs' online communication strategy and marketing strategy. This study has three main practical implications for SMEs considering using social media technology. First, we progress theory by extending the diffusion of innovation (DOI) theory on a burgeoning but seemingly interminable phenomenon of social media marketing. Evidence from extant literature in the light of social media marketing among firms shows a dearth of research grounded on theories. The current study thus offers a modest contribution in that regard by providing empirical support from a social media perspective for the largely accepted DOI theory (Rogers, 1983) with a conceptual framework that exhibits good explanatory power. Secondly, literature on social media exhibits fewer studies that integrate and examine the relationships among the constructs used in this study, particularly from SMEs' perspectives. Thirdly, the most widely used social media applications were social networking services. The applications adopted corresponded closely with the most popular social media tools used by citizens locally and regionally. This implies that the SMEs in this study were using these applications for external communication purposes, which also corresponds with a study of (Ahmad et al., 2019) on social media use by European SMEs. Therefore, SMEs that wishes to use social media as part of their organization's strategy should adopt applications that are popular in their respective domains or context (geography or target market profiles).

As the study shows the importance of instagram use effectively and also a significant impact on performance, therefore, companies need to consider the strategies to adopt respective social media tools (e.g. instagram, Facebook, etc). As such, our results strongly indicate that fostering the level of social media use could also be beneficial especially for SMEs to attract the desired customers through social media marketing. Study findings support that social media deployment can affect the both financial and non-financial performance of SMEs.

Additionally, the research findings also provide useful implications not only for financial performance and non-financial performance but also for the social media service providers. The innovative behavior towards social media use, and more specifically about the importance they attach to certain selection criteria, can help social media service providers to increase the value delivered from the social media services they provide to SMEs.

In conclusion, there is little evidence of the benefits of social media adoption on financial performance and non-financial performance. Despite the possible advantages of using social networks, few studies have examined this (Öztamur \& 
Karakadılar, 2014; Vásquez \& Escamilla, 2014) and most results, like ours, are inconclusive (Ali-Hassan, Nevo, \& Wade, 2015; Lovejoy \& Saxton, 2012).

Some of the limitations of this study include the specific target sample (Malaysian SMEs), sampling method (i.e, nonprobability sampling), measures of firm's performances, and collecting data from a similar type of respondents. To overcome these limitations, future studies should be conducted among all Malaysian ethnic groups including Malaysian Chinese, Malay, and Indian enterprises.

Concluding, a thorough investigation of the determinants of the degree of social media use for business in the SME's can be promising and serve for further research. First, although the results of our study can be used to advance our understanding of the organizational factors that influence social media use, future research should continue to examine the impact of size and star rating on the adoption of social media use, as well as the development and testing of a more integrated framework elaborating not only on additional organizational factors, but also managerial, technological and environmental factors relevant to SME's. Additionally, the orientation of future attempts should be focused on examining determinants of the level of involvement in each of the social media platforms separately. Secondly, the present study can serve as a starting point for exploring further the type of social media tools adopted by SMEs to achieve their marketing and communication objectives. Thirdly, future research should be directed towards whether the decision to engage in social media tools based on specific selection criteria are related to increased levels of organizational effectiveness. For example, it would be of great interest to examine whether the selection of social media tools that have been selected in terms of cost or functionality, maybe a misleading practice that does not serve the marketing and communication objectives of SMEs. Finally, to address the research problem more in-depth, future research should be conducted into different industries, other contexts, and other countries. Future research should be based on these elements to broaden our knowledge of the impact of social media usage on firm performance. Despite its limitations, the current study provides a starting point for understanding factors that enhance the use of social media strategies in the SME context. Social media engagement and managing user-generated content on social media platforms comprise great challenges for SME professionals. Along with traditional means, social media can provide SMEs with the opportunity to successfully implement the marketing and communication strategy for the benefit of the SME's. 


\section{References}

Abbas, M. W., \& Ul Hassan, M. (2017). Moderating impact of environmental turbulence on business innovation and business performance. Pakistan Journal of Commerce and Social Sciences (PJCSS), 11(2), 576-596.

Abdallah, W. M., \& Alnamri, M. (2015). Non-financial performance measures and the BSC of multinational companies with multi-cultural environment: An empirical investigation. Cross Cultural Management.

Agostino, D., \& Sidorova, Y. (2016). A performance measurement system to quantify the contribution of social media: new requirements for metrics and methods. Measuring Business Excellence.

Agung, N. F. A., \& Darma, G. S. (2019). Opportunities and Challenges of Instagram Algorithm in Improving Competitive Advantage. International Journal of Innovative Science and Research Technology, 4(1), 743-747.

Ahmad, S. Z., Bakar, A. R. A., \& Ahmad, N. (2019). Social media adoption and its impact on firm performance: the case of the UAE. International Journal of Entrepreneurial Behavior \& Research.

Ainin, S., Parveen, F., Moghavvemi, S., Jaafar, N. I., \& Shuib, N. L. M. (2015). Factors influencing the use of social media by SMEs and its performance outcomes. Industrial Management \& Data Systems.

Al-kalouti, J., Kumar, V., Kumar, N., Garza-Reyes, J. A., Upadhyay, A., \& Zwiegelaar, J. B. (2020). Investigating innovation capability and organizational performance in service firms. Strategic Change, 29(1), 103-113.

Alber, J. M., Bernhardt, J. M., Stellefson, M., Weiler, R. M., Anderson-Lewis, C., Miller, M. D., \& MacInnes, J. (2015). Designing and testing an inventory for measuring social media competency of certified health education specialists. Journal of medical Internet research, $17(9), \mathrm{e} 221$

Ali-Hassan, H., Nevo, D., \& Wade, M. (2015). Linking dimensions of social media use to job performance: The role of social capital. The Journal of Strategic Information Systems, 24(2), 65-89.

Archibald, M. M., \& Clark, A. M. (2014). Twitter and nursing research: how diffusion of innovation theory can help uptake. Journal of Advanced Nursing, 70(3), e3-5.

Ashley, C., \& Tuten, T. (2015). Creative strategies in social media marketing: An exploratory study of branded social content and consumer engagement. Psychology \& Marketing, 32(1), 15-27.

Bala, H., Massey, A., \& Seol, S. (2019). Social media in the workplace: Influence on employee agility and innovative behavior. Paper presented at the Proceedings of the 52nd Hawaii International Conference on System Sciences.

Bao, H., Li, B., Shen, J., \& Hou, F. (2016). Repurchase intention in the Chinese e-marketplace: Roles of interactivity, trust and perceived effectiveness of e-commerce institutional mechanisms. Industrial Management \& Data Systems.

Bass, F. M. (1969). A new product growth for model consumer durables. Management science, 15(5), 215-227.

Baumöl, U., Hollebeek, L., \& Jung, R. (2016). Dynamics of customer interaction on social media platforms. Electronic Markets, 26(3), 199202.

Breslauer, B., \& Smith, T. (2009). Social media trends around the world! The global web index (GWI). ESOMAR Research, Online Research, Chicago.

Casaló, L. V., Flavián, C., \& Ibáñez-Sánchez, S. (2020). Influencers on Instagram: Antecedents and consequences of opinion leadership. Journal of Business Research, 117, 510-519.

Charoensukmongkol, P., \& Sasatanun, P. (2017). Social media use for CRM and business performance satisfaction: The moderating roles of social skills and social media sales intensity. Asia Pacific Management Review, 22(1), 25-34.

Chen, E. T. (2016). Impacts of Social Media on Today's Businesses. In Encyclopedia of E-Commerce Development, Implementation, and Management (pp. 2030-2038): IGI Global.

Colliander, J., \& Dahlén, M. (2011). Following the fashionable friend: The power of social media: Weighing publicity effectiveness of blogs versus online magazines. Journal of advertising research, 51(1), 313-320.

Daoud, H., \& Triki, M. (2013). Accounting information systems in an ERP environment and tunisian firm performance. International Journal of Digital Accounting Research, 13.

Dodokh, A., \& Al-Maaitah, M. A. (2019). Impact of social media usage on organizational performance in the Jordanian dead sea cosmetic sector. European Journal of Business and Management, 11(2), 75-91.

Dong-Hun, L. (2010). Korean consumer \& society: growing popularity of social media and business strategy. Seri Quarterly, 3(4), 112.

Doyle, J. P., Su, Y., \& Kunkel, T. (2020). Athlete branding via social media: examining the factors influencing consumer engagement on Instagram. European Sport Management Quarterly, 1-21.

Durkin, M., McGowan, P., \& Murray, L. (2014). Perspectives on the potential for social media to improve communication in small businessbank relationships. The International Journal of Entrepreneurship and Innovation, 15(4), 251-264.

Elaluf-Calderwood, S., Kietzmann, J., \& Saccol, A. Z. (2005). Methodological approach for mobile studies: empirical research considerations. Paper presented at the 4th European conference on research methodology for business and management studies.

Elliot, R., \& Boshoff, C. (2005). The influence of organisational factors in small tourism businesses on the success of Internet marketing. Management Dynamics: Journal of the Southern African Institute for Management Scientists, 14(3), 44-58.

Fornell, C., \& Larcker, D. F. (1981). Structural equation models with unobservable variables and measurement error: Algebra and statistics. In: Sage Publications Sage CA: Los Angeles, CA.

Goldfarb, A., \& Tucker, C. E. (2011). Privacy regulation and online advertising. Management science, 57(1), 57-71.

Gwadabe, U. M., \& Amirah, N. A. (2017). Entrepreneurial competencies: SMES performance factor in the challenging Nigerian economy. Academic Journal of Economic Studies, 3(4), 55-61.

Hair, J., Hollingsworth, C. L., Randolph, A. B., \& Chong, A. Y. L. (2017). An updated and expanded assessment of PLS-SEM in information systems research. Industrial Management \& Data Systems.

Hair, J. F., Risher, J. J., Sarstedt, M., \& Ringle, C. M. (2019). When to use and how to report the results of PLS-SEM. European business review.

Hanna, R., Rohm, A., \& Crittenden, V. L. (2011). We're all connected: The power of the social media ecosystem. Business horizons, 54(3), 265-273.

Honey, M., \& Raphael, D. (2017). Preparation for working in a knowledge-based society: New Zealand student nurses' use of social media. Paper presented at the Informatics.

Huang, W., Yuan, C., \& Li, M. (2019). Person-job fit and innovation behavior: Roles of job involvement and career commitment. Frontiers in psychology, 10, 1134 .

Jafri, M. H. (2010). Organizational commitment and employee's innovative behavior: A study in retail sector. Journal of Management Research, $10(1), 62-68$.

Kaplan, A. M., \& Haenlein, M. (2010). Users of the world, unite! The challenges and opportunities of Social Media. Business horizons, 53(1), 59-68. 
Karampela, M., Lacka, E., \& McLean, G. (2020). "Just be there": Social media presence, interactivity, and responsiveness, and their impact on B2B relationships. European Journal of Marketing.

Kettunen, J. (2017). Career practitioners' conceptions of social media and competency for social media in career services. In: University of Jyväskylä, Finnish Institute for Educational Research.

Kim, N., \& Kim, W. (2018). Do your social media lead you to make social deal purchases? Consumer-generated social referrals for sales via social commerce. International Journal of Information Management, 39, 38-48.

Knoll, J. (2016). Advertising in social media: a review of empirical evidence. International journal of Advertising, 35(2), 266-300.

Korda, H., \& Itani, Z. (2013). Harnessing social media for health promotion and behavior change. Health promotion practice, 14(1), $15-23$.

Kumar, A., Bezawada, R., Rishika, R., Janakiraman, R., \& Kannan, P. (2016). From social to sale: The effects of firm-generated content in social media on customer behavior. Journal of Marketing, 80(1), 7-25.

Lebherz, P. R. (2011). Relevant factors for the impact of social media marketing strategies: Empirical study of the internet travel agency sector.

Lee, H. H., Fiore, A. M., \& Kim, J. (2006). The role of the technology acceptance model in explaining effects of image interactivity technology on consumer responses. International Journal of Retail \& Distribution Management.

Lee, S., \& Cho, M. (2011). Social media use in a mobile broadband environment: Examination of determinants of Twitter and Facebook use. International Journal of Mobile Marketing, 6(2), 71-87.

Lee, Y., \& Kozar, K. A. (2012). Understanding of website usability: Specifying and measuring constructs and their relationships. Decision support systems, 52(2), 450-463.

Leung, D., Law, R., Van Hoof, H., \& Buhalis, D. (2013). Social media in tourism and hospitality: A literature review. Journal of travel \& tourism marketing, 30(1-2), 3-22.

Liu, Y., \& Shrum, L. J. (2002). What is interactivity and is it always such a good thing? Implications of definition, person, and situation for the influence of interactivity on advertising effectiveness. Journal of advertising, 31(4), 53-64.

Lovejoy, K., \& Saxton, G. D. (2012). Information, community, and action: How nonprofit organizations use social media. Journal of computer-mediated communication, 17(3), 337-353.

Lundblad, J. P. (2003). A review and critique of Rogers' diffusion of innovation theory as it applies to organizations. Organization Development Journal, 21(4), 50.

Maddux, J. E., \& Rogers, R. W. (1983). Protection motivation and self-efficacy: A revised theory of fear appeals and attitude change. Journal of experimental social psychology, 19(5), 469-479.

Mansour, K. M. A., \& Al-Najjar, F. J. S. (2018). The Social Media Usage and its Impact on the Innovative Behavior: The Mediator Role of Information Technology: A Field Study in the Information and Communication Technology Organizations in Jordan. International Journal of Business and Management, 13(11)

McCann, M., \& Barlow, A. (2015). Use and measurement of social media for SMEs. Journal of small business and enterprise development.

Messmann, G., \& Mulder, R. H. (2012). Development of a measurement instrument for innovative work behaviour as a dynamic and contextbound construct. Human Resource Development International, 15(1), 43-59.

Molla, A., \& Heeks, R. (2007). Exploring e-commerce benefits for businesses in a developing country. The Information Society, 23(2), 95108 .

Monica, B., \& Balaş, R. (2014). Social media marketing to increase brand awareness. Journal of Economics and Business Research, 20(2), $155-164$.

Napitupulu, I. H., \& Dalimunthe, A. R. (2015). The influence of information system user competency and the quality of management accounting information systems on user satisfaction. Australian Journal of Basic and Applied Sciences, 9(31), 660-667.

Odoom, R., Anning-Dorson, T., \& Acheampong, G. (2017). Antecedents of social media usage and performance benefits in small-and medium-sized enterprises (SMEs). Journal of Enterprise Information Management.

Okazaki, S., \& Taylor, C. R. (2013). Social media and international advertising: theoretical challenges and future directions. International marketing review.

Orús, C., Barlés, M. J., Belanche, D., Casaló, L., Fraj, E., \& Gurrea, R. (2016). The effects of learner-generated videos for YouTube on learning outcomes and satisfaction. Computers \& Education, 95, 254-269.

Ostrom, A. L., Parasuraman, A., Bowen, D. E., Patrício, L., \& Voss, C. A. (2015). Service research priorities in a rapidly changing context. Journal of Service Research, 18(2), 127-159.

Öztamur, D., \& Karakadilar, İ. S. (2014). Exploring the role of social media for SMEs: as a new marketing strategy tool for the firm performance perspective. Procedia-Social and behavioral sciences, 150, 511-520.

Paniagua, J., \& Sapena, J. (2014). Business performance and social media: Love or hate? Business horizons, 57(6), 719-728.

Park, Y. K., Song, J. H., Yoon, S. W., \& Kim, J. (2014). Learning organization and innovative behavior: The mediating effect of work engagement. European Journal of Training and Development.

Parveen, F., Jaafar, N. I., \& Ainin, S. (2015). Social media usage and organizational performance: Reflections of Malaysian social media managers. Telematics and informatics, 32(1), 67-78.

Parveen, F., Jaafar, N. I., \& Ainin, S. (2016). Social media's impact on organizational performance and entrepreneurial orientation in organizations. Management Decision.

Quan-Haase, A., \& Young, A. L. (2010). Uses and gratifications of social media: A comparison of Facebook and instant messaging. Bulletin of science, technology \& society, 30(5), 350-361.

Rahayu, R., \& Day, J. (2015). Determinant factors of e-commerce adoption by SMEs in developing country: evidence from Indonesia. Procedia-Social and behavioral sciences, 195, 142-150.

Rahman, K. A. A., Jalil, N. A., Arsada, M. A. M., Hashim, S., Rahim, M. B., Yunus, F. A. N., . . Ismail, M. E. (2021). Development of Mobile Application Framework Based on Competency-Based Education for Technical and Vocational Education. Journal of Technical Education and Training, 13(2), 44-52.

Ramdani, B., Chevers, D., \& Williams, D. A. (2013). SMEs' adoption of enterprise applications: A technology-organisation-environment model. Journal of small business and enterprise development.

Rogers, E. M. (1995). Diffusion of Innovations: modifications of a model for telecommunications. In Die diffusion von innovationen in der telekommunikation (pp. 25-38): Springer.

Rogers, M. (2004). Networks, firm size and innovation. Small business economics, 22(2), 141-153.

Rutter, R., Roper, S., \& Lettice, F. (2016). Social media interaction, the university brand and recruitment performance. Journal of Business Research, 69(8), 3096-3104.

Saffer, A. J., Sommerfeldt, E. J., \& Taylor, M. (2013). The effects of organizational Twitter interactivity on organization-public relationships. Public relations review, 39(3), 213-215. 
Sajilan, S., \& Tehseen, S. (2019). Network competence and firm performance: The mediating role of entrepreneurial innovativeness among Malaysian Chinese entrepreneurs of wholesale businesses. Asian Academy of Management Journal, 24(Supp. 1), $187-201$.

Sajilan, S., Tehseen, S., Yafi, E., \& Ting, X. (2019). Impact of Facebook usage on firm's performances among Malaysian Chinese retailers. Global Business \& Finance Review (GBFR), 24(4), 45-62.

Scott, S. G., \& Bruce, R. A. (1994). Determinants of innovative behavior: A path model of individual innovation in the workplace. Academy of management journal, 37(3), 580-607.

Shuai, J.-J., \& Wu, W.-W. (2011). Evaluating the influence of E-marketing on hotel performance by DEA and grey entropy. Expert systems with applications, $38(7), 8763-8769$

Shunlong, X., \& Weiming, Z. (2012). The relationships between transformational leadership, LMX, and employee innovative behavior. Journal of Applied Business and Economics, 13(5), 87-96.

Soong, H.-C., Jalil, N. B. A., Ayyasamy, R. K., \& Akbar, R. (2019). The essential of sentiment analysis and opinion mining in social media: Introduction and survey of the recent approaches and techniques. Paper presented at the 2019 IEEE 9th symposium on computer applications \& industrial electronics (ISCAIE).

Spita, M., Peitzika, E., \& Chatzi, S. (2020). Social media adoption among small and medium-sized Greek hotels: a survey about its antecedents and its impact on performance outcomes. International Journal of Decision Sciences, Risk and Management, 9(1-2), 23-54.

Stokes, R. (2013). eMarketing: The essential guide to marketing in a digital world: Quirk eMarketing.

Stratman, J. K., \& Roth, A. V. (2002). Enterprise resource planning (ERP) competence constructs: two-stage multi-item scale development and validation. Decision Sciences, 33(4), 601-628.

Sundar, S. S., Kalyanaraman, S., \& Brown, J. (2003). Explicating web site interactivity: Impression formation effects in political campaign sites. Communication research, 30(1), 30-59.

Tan, K. S., Chong, S. C., Lin, B., \& Eze, U. C. (2009). Internet-based ICT adoption: evidence from Malaysian SMEs. Industrial Management \& Data Systems.

Teeratansirikool, L., Siengthai, S., Badir, Y., \& Charoenngam, C. (2013). Competitive strategies and firm performance: the mediating role of performance measurement. International Journal of Productivity and Performance Management.

Teo, T. S., \& Choo, W. Y. (2001). Assessing the impact of using the Internet for competitive intelligence. Information \& management, 39(1), 67-83.

Toole, T. (2011). Social media: key tools for the future of work-based learning. Development and Learning in Organizations: An International Journal.

Trusov, M., Bucklin, R. E., \& Pauwels, K. (2009). Effects of word-of-mouth versus traditional marketing: findings from an internet social networking site. Journal of Marketing, 73(5), 90-102.

Vásquez, G. A. N., \& Escamilla, E. M. (2014). Best practice in the use of social networks marketing strategy as in SMEs. Procedia-Social and behavioral sciences, 148, 533-542.

Yamamoto, T., \& Miyashita, R. (2008). A Progress Report and a Proposal: Interactivity in Ubiquitous Learning Enhanced by Virtual Tutors in e-Learning Contents. Paper presented at the 2008 IEEE International Conference on Sensor Networks, Ubiquitous, and Trustworthy Computing (sutc 2008).

Yuan, F., \& Woodman, R. W. (2010). Innovative behavior in the workplace: The role of performance and image outcome expectations. Academy of management journal, 53(2), 323-342.

Zappe, J. (2010). The ROI of social media. Journal of Corporate Recruiting Leadership, 5(3), 3-9.

Zhu, S., Hao Yang, H., Xu, S., \& MacLeod, J. (2020). Understanding social media competence in higher education: Development and validation of an instrument. Journal of Educational Computing Research, 57(8), 1935-1955. 